\title{
DO PROFANO AO SAGRADO: AS TERRITORIALIDADES DO CENTRO ESPÍRITA SÃO SEBASTIÃO (CESS), EM BELO HORIZONTE, MINAS GERAIS ${ }^{1}$
}

\author{
FROM THE PROFANE TO THE SACRED: THE TERRITORIALITIES OF THE CENTRO \\ SÃO SEBASTIÃO (CESS), IN BELO HORIZONTE, MINAS GERAIS
}

Carollina Garcia de Barcelos

Geógrafa pela PUC Minas, Brasil

carollbarcelos.geografia@gmail.com

Luiz Eduardo Panisset Travassos

Geógrafo, Professor permanente do Programa de Pós-Graduação

em Geografia da PUC Minas e professor colaborador do PPGGeo da UFMG, Brasil

luizepanisset@gmail.com

Pedro Henrique Dias Ferreira

Geógrafa pela PUC Minas, Brasil

pedro.dias@sga.pucminas.br

\section{Rodrigo Corrêa Teixeira}

Geógrafo, Professor permanente do Programa de Pós-Graduação em

Geografia da PUC Minas, Brasil

rteixeira@pucminas.br

\section{Resumo}

O presente trabalho tem como objetivo principal a pesquisa e o mapeamento do território e das territorialidades do Centro Espírita São Sebastião (CESS), em Belo Horizonte, Minas Gerais. Para isso, é fundamental compreender os conceitos de território e territorialidade, bem como aqueles que fazem referência ao sagrado e ao profano sob a ótica da geografia da religião. Neste trabalho o território será entendido como o Centro Espírita São Sebastião, espaço definido desde a década de 1940, a fim de se compreender como três religiões distintas são capazes de ocupar o mesmo território, ainda que apresentem significados sociais, míticos e simbólicos únicos unindo fiéis para experienciar realidades tão diferentes.

Palavras-chave:Geografia Cultural, Geografia da Religião,Território, Territorialidade.

\begin{abstract}
The study has as main objective the research and mapping of the territory and territorialities of the Centro Espírita São Sebastião (CESS), in Belo Horizonte, Minas Gerais. For this, it is fundamental to understand the concepts of territory and territoriality and those that refer to the sacred and the profane from the perspective of the Geography of Religion. In this work, the territory will be understood as the Centro Espírita São Sebastião (CESS), a space

\footnotetext{
${ }^{1}$ Trabalho final em virtude da pesquisa PIBIC PIBIC-2019/23322 da Pontifícia Universidade Católica de Minas Gerais.
} 
defined since the 1940s, in order to understand how three distinct religions are capable of occupying the same territory, even though they present unique social, mythical and symbolic meanings uniting different members to experience such different realities.

Keywords: Cultural Geography, Geography of Religion, Territory, Territoriality.

\section{INTRODUÇÃO}

De acordo com Góis (2013, p. 351), "o território está diretamente relacionado ao alcance das ações dos homens ou de grupos humanos situados numa determinada posição deste solo planetário." Além disso, a ação humana será permanentemente uma ação espacial - por estarem situados - e da mesma forma temporal - por ser compreendido na forma contínua do passado, presente e futuro (GÓIS, 2013, p. 351). Neste trabalho, o território será entendido como o Centro Espírita São Sebastião, espaço definido desde a década de 1940.

Já a territorialidade será percebida como "multidimensionalidade do 'vivido' territorial" que é perceptível em "todas as escalas espaciais e sociais" (RAFFESTIN, 1983, p.158-161 apud SAHR, 2007, p.59). Ou seja, o ser humano, ao ser racional e possuidor da liberdade, irá associar os seus interesses e aqueles do seu grupo social a interesses variados de outros sujeitos ou grupos, unindo em uma mesma territorialidade, espacialidades diferentes.

Assim, sob a perspectiva de Vargas (2007, p.166) "o território pode ser visto como espaço de articulação, de negociação (...), para onde confluem ações, para onde convergem as rearticulações, abarcando aspectos objetivos e subjetivos das relações que nele celebram". Desta maneira, as territorialidades nessa pesquisa são as da Umbanda, do Congado e do Candomblé, religiões conhecidas como a como a Tríade Bantu.

A fundação do CESS ocorreu em um tempo de perseguições, discriminações e cercamentos dos direitos civis, políticos e religiosos, coincidindo com a criação de vários outros centros (SANTOS, 2015, p. 37). Consta que "os primeiros registros de terreiro de Umbanda na capital mineira são da década de 30, quando a cidade ainda começava a experimentar um processo de crescimento" (MORAIS, 2010, p.101).

Percebe-se que o próprio uso do termo "centro espírita" é uma nomeação genérica que esconde as raízes africanas das religiões justamente devido ao preconceito e repressão ocorridos à época e, infelizmente, ainda hoje. De acordo com Silva (1995, p.165) compreende-se que, "na luta pelo que pode ou não pode existir na cidade (no mundo real 
ou imaginário que ela representa), a presença física e institucional do terreiro foi motivo de grande perseguição e discriminação social".

Para abordar as territorialidades do CESS é necessário definir a Tríade Bantu, ou seja, o exercício ritualístico das três manifestações religiosas de matriz africana Bantu: a Umbanda, o Congado e o Candomblé de Angola cultuadas no mesmo território, como acontece no CESS. Morais afirma que “(...) Cecília Félix dos Santos, a Tabaladê D’Ogum, (...), teve um terreiro de umbanda antes de ser iniciada no candomblé, sendo que ainda mantinha uma guarda de congado (...)" (MORAIS, 2010, p. 95). Percebe-se que praticar rituais “(...) nas várias linhas apresenta-se (...) como uma forma de garantir a sobrevivência do terreiro através de um leque maior de opções de culto e de atendimento oferecido aos seus frequentadores" (SILVA, 1995, p.101). Esse método foi empregado por D. Cecília e fica visível na análise do dia a dia do CESS.

A Umbanda é um culto religioso verdadeiramente brasileiro que reverencia matrizes africanas, asiáticas, europeias e indígenas, preconizando entidades da pluralidade mítica nas práticas que resumem "o culto da natureza de origem étnica iorubá e Bantu." (SANTOS, 2015, p.44). Esse culto se define pela descida dos espíritos de índios e negros antepassados por meio dos médiuns. De acordo com Kardec (2003, p. 234), "todo aquele que sente, num grau qualquer, a influência dos Espíritos é, por esse fato, médium."

No Centro Espírita São Sebastião “caminha-se pelo rosário”, sentença utilizada pelos religiosos que simboliza servir a fé em Nossa Senhora do Rosário, por meio dos ritos. Os devotos cultuam os santos católicos, nas datas respectivas ao longo do ano, acompanhando a orientação do calendário litúrgico.

O Candomblé de Angola no CESS é guiado pelos princípios que amparam essa manifestação religiosa, como a hierarquia, o orô (segredo de tradição) e o preceito. Constata-se que, "no candomblé, existe uma hierarquia que deve ser estabelecida de acordo com o tempo de iniciação de cada participante" (MORAIS, 2010, p. 101).

Sendo assim, o trabalho apresenta o objetivo geral pesquisar o território e as territorialidades do Centro Espírita São Sebastião (CESS), sendo auxiliado pelos seguintes objetivos específicos: a) Caracterizar a Umbanda, o Congado e o Candomblé de Angola de matriz Bantu; b) Compreender e relacionar os conceitos de território e territorialidade no CESS e c) Identificar de que forma as três vertentes religiosas sobrevivem em um mesmo território.

Com a preocupação de que esta pesquisa seja dotada de qualidade científica e normativa, foi desenvolvida uma pesquisa descritiva com abordagem qualitativa, com 
objetivo de compreender e interpretar determinados aspectos imateriais. Os procedimentos utilizados foram a revisão bibliográfica e a adoção da metodologia de observação participante.

Uma parte do trabalho se desenvolveu seguindo as linhas gerais das pesquisas de Tuan (1979/2006, 1980, 1983), principalmente por meio do estudo da relação das pessoas com a natureza e dos seus sentimentos em relação aos espaços e lugares. A pesquisa aos trabalhos de Elíade $(1956,1983,1991,1994,1995,1999)$ ocorreu em função da temática ser relacionada às religiões, ao imaginário, aos simbolismos e a relação entre o sagrado e profano.

As contribuições da Geografia da Religião foram encontradas em de Gill Filho (2001, 2002, 2005, 2006, 2007, 2008), Kozel (2002) e Rosendahl (1996, 1999, 2002, 2003, 2007) e, para se compreender os conceitos de território e territorialidades, os pesquisadores buscaram apoio em Góis (2011; 2013), Sahr (2007) e Vargas (2007).

Especificamente em relação ao Centro Espírita São Sebastião buscou-se apoio nos trabalhos de Silva (1995), Santos (2005) e Morais (2010).

No tocante às religiões de matriz africana, as principais fontes foram Bastide (1971, 2006), Carneiro (1991), Costa (1996), Oliveira e Travassos (2015), Oliveira (2014) e Silva $(1995 ; 2007)$.

\section{ORIGEM E DISSEMINAÇÃO DAS RELIGIÕES DE MATRIZ AFRICANA NO BRASIL}

Se de um lado a ideia de uma cultura e/ou religião africana que une todos os variados povos bantus em um patrimônio cultural comum é praticamente impossível, de outro percebe-se a existência de uma certa uniformidade e parentesco de base (VICENTE, 2012). De acordo com Altuna (1985, p.9), os povos bantus possuem uma unidade cultural básica, englobando pessoas que apresentam características étnicas e culturais comuns e formam um dos grupos humanos mais importantes da África. Portanto, não se deve discutir a unidade cultural bantu, uma vez que é possível observar pluralidade e diversidade nas formas culturais bantus devido ao grande agrupamento de etnias, ciclos culturais, dialetos e línguas (Figura 1).

Assim, referimos ao povo Bantu como um macro grupo cultural habitando grandes áreas da África Centro-Ocidental. Seus costumes, leis e atividades os definiam. Iniciaram a agricultura e a metalurgia. Praticavam feitiços individuais e coletivos, magias e rituais, eram monoteístas, acreditavam em uma divindade superior que havia criado as coisas boas que estavam localizadas nos céus e as coisas más que se encontravam nas águas. 
Cultuavam espíritos da natureza. Para Vasconcelos (2007), "o mundo era dividido em natural e sobrenatural; havia o mundo dos vivos (negros) e o dos mortos (brancos), separados entre si pela água. No mar, onde estavam os mortos, era o mundo do além, que é habitado pelos ancestrais e diversos espíritos. E, por meio de rituais, prestavam-Ihes homenagens e obediência e lhes ofertavam presentes (VASCONCELOS, 2007, p. 26).

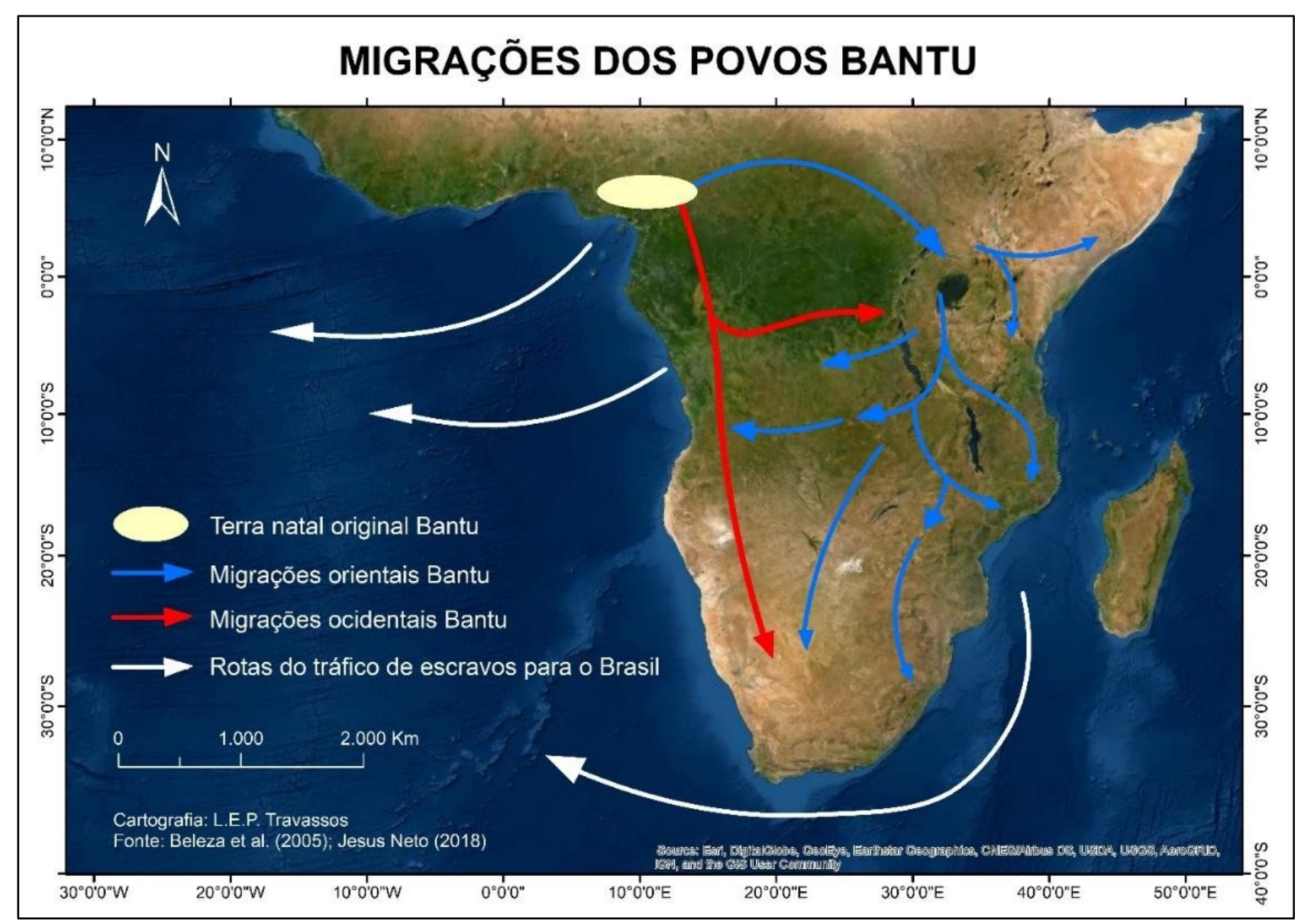

Figura 1 - Rotas migratórias das etnias Bantu na África e a partir do continente. Fonte: Elaborado pelos autores.

Os povos Bantu chegaram ao Brasil pelos navios negreiros portugueses em meados de 1550 (FAUSTO, 1996). De acordo com Carneiro (1936), com o tráfico foram para os estados do Maranhão, Pernambuco e no Rio de Janeiro, onde, por meio de migrações menores, se deslocaram para Alagoas, litoral do Pará, São Paulo e assim chegando também em Minas Gerais, trazendo consigo aspectos de sua cultura como a religião. 


\subsection{O Candomblé de Angola no Brasil}

Desde o século XVI até o século XIX, de acordo com Kileuy e Oxaguiã (2016), africanos de grupos culturais e étnicos variados, geralmente rivais, foram capturados e trazidos como escravos para o Brasil.

Como os bantos, que vieram de regiões atualmente conhecidas, como Angola, Congo, Guiné, Moçambique, Zaire etc. (Os primeiros deste grupo a chegar, por volta de 1559 a 1560, foram trazidos do Congo.) Os fons, provenientes do Benim, antigo Daomé. Do Togo foram trazidos os ewes. Os iorubás, de cidades da atual Nigéria, como llexá, Oyó, Ketu, Abeokutá, Ekiti, Ondô, ljexá, Egbá, Egbado etc. Da região de Gana vieram os ashantis, os minas. E trouxeram com eles milênios de diferentes culturas e de religiosidades que aqui se reorganizaram, criando o candomblé (KILEUY; OXAGUIÃ, 2016, p. 32).

Kileuy e Oxaguiã (2016) afirmam que a dispersão das pessoas escravizadas no Brasil foi enorme, fato que favoreceu a separação de famílias inteiras e grupos étnicos. Contudo, não foi muito difícil para os sujeitos escravos começarem a manter contato uns com os outros, por causa do comércio escravagista. Foram compreendendo o idioma local e obtiveram um vínculo tribal, sem, no entanto, ter acabado com a sua identidade nativa. Ao que tudo indica, os bantus sentiram mais dificuldades em usar a língua da nova terra, talvez pelo fato de viverem mais solitários e mais distantes dos centros urbanos. Os bantos comunicavam-se mais em suas línguas, conservando-se longe dos outros. Organizavam grupos e, assim, conseguiram manter suas crenças, seus costumes e o fervor religioso, sobrevivendo do seu amor aos ancestrais e divindades.

Embora tivessem divindades semelhantes, quando os cativos se reuniam nos terreiros para celebrá-las, era a África-mãe que estava sendo representada naquele momento. Nesta hora, o espaço se tornava lugar sagrado, pois alí habitavam orixás, inquices e voduns (KILEUY; OXAGUIÃ, 2016).

O candomblé de angola engloba, sobretudo, o cerimonial congo e cabinda, busca destacar a tradição das religiões bantus. Essa nação, apesar de ser a mais popular e a mais exercida pelo "povo-de-santo", é percebida por membros de outras nações como confusa, pois abrange um panteão bem mais extenso. Cultua, além dos inquices (divindades bantus), os orixás, os voduns, os vunjes (espíritos infantis) e os caboclos. Nos terreiros do candomblé de angola, os atabaques são tocados com as mãos e as zuelas (cantigas) contém muitos termos em português. Os ritmos típicos são a kabula, o congo e o barravento ou muzenza (SILVA, 2005). 
O candomblé de angola, pelo vasto afluxo e difusão dos bantus no Brasil, espalhouse por quase todo o território, possuindo influências ameríndias e católicas. Assim, devido a essa pluralidade religiosa, a mesma religião recebeu nomes próprios em alguns estados (e.g.: cabula, no Espírito Santo; candomblé de caboclo, na Bahia; macumba, no Rio de Janeiro). Nota-se que esses cultos receberam influência da nação jeje-nagô e, geralmente, não é possível discernir qual das nações predominou nos terreiros.

Portanto, a ancestralidade africana como parâmetro para pertencer ao culto foi descartada e os inquices, orixás e voduns tornaram-se deuses/divindades adorados por parte da sociedade que "passou a incorporá-los, conhecer seus mitos e fundamentos (segredos rituais) e tê-los como suas entidades espirituais regentes, independentemente de sua cor e origem" (SILVA, 2005, p. 68).

\subsection{A Umbanda no Brasil}

A princípio, Umbanda é uma palavra de origem Bantu que significa chefe supremo do culto, feiticeiro, médico, adivinho, espaço de macumba ou seu ritual (SILVA, 1995, p.167). A composição dessa religião se deu pelo processo de aculturação, em que diversos aspectos religiosos se cruzaram, se combinaram e se integraram. Durante esse processo, a conformidade surgiu da miscigenação de vários princípios religiosos provenientes da África e agregados aos da nova terra gerando, assim, uma nova identidade religiosa. Esta é consequência do convívio de elementos ameríndios, candomblecistas, católicos, espíritas e orientais, sendo designada umbanda.

Na prática da Umbanda percebe-se o sincretismo de elementos litúrgicos dessa religião e convoca os cientistas a analisar a umbanda em seus fatores culturais e identitários, relevando a memória dos migrantes africanos. No Brasil, a sociedade latifundiária e patriarcal vivia de acordo com o regime de castas étnicas, organização diversificada daquela fundamentada na família e nas organizações clânicas africanas, guiadas "pelo compromisso existencial e pelo cotidiano religioso característico dos povos Bantu". (SANTOS, 2015, p. 45).

A tradição Bantu no Brasil é uma passagem quase nova na etnografia afro religiosa, o que complica indicar com clareza os vínculos com outras formas de rito e o seu avanço no decorrer do tempo. É viável que a umbanda tenha inspirado o candomblé e as macumbas e pode ter experimentado uma acelerada interação dos tipos míticos, apesar de nem sempre vista, é o que especifica sua afirmativa: “(...) eu procurei em vão entre os afro- 
baianos vestígios religiosos descendentes dos negros banto." (RODRIGUES apud RAMOS, 2001, p. 86).

Santos (2015, p.45) afirma que as raízes "originais" do culto da umbanda teriam aparecido do Calundu, da Cabula, "cerimônias Bantu-angolesas, cultuadas no Nordeste e no Sudeste do Brasil”. O mesmo aconteceu com o candomblé de caboclos, na Bahia.

A umbanda retratou os processos de urbanização, condensando o culto dos "deuses da natureza", dos orixás de gênese iorubá e minkises (ancestrais) bantu, com a incorporação dos espíritos indígenas e negros no corpo dos médiuns. Simultaneamente, buscou adaptar-se à mudança política com seus atuais valores, ficando penoso identificar os fundamentos autênticos de origem. Com o passar dos anos, algumas características originais foram se transformando e os atabaques passaram a ser utilizados em alguns terreiros. Na umbanda os atabaques são tocados com as mãos e os pontos entoados em português, com o intuito de manifestação, de trabalho e de desincorporação.

\subsection{O Congado no Brasil}

No Brasil, o congado ocorre desde a época do Brasil Colônia e se baseia na troca de princípios da religião africana com elementos portugueses incorporados à época. Consiste como uma festa popular afro-brasileira e é evidenciado pelas tradições históricas e míticas da coroação de um rei do Congo (SOUZA, 2001; SANTOS, 2012; NERY, 2012).

A guardas no congado retratam a coroação de um rei do Congo por meio de cantos e danças. Tais manifestações são efetuadas com o acompanhamento de um padre (SANTOS, 2012), embora nem sempre isso ocorra. Cascudo (2000, p.50) identifica o congado como uma ocorrência efetivamente brasileira quando afirma que "a congada nunca existiu na África”. Para Gomes e Pereira (2000, p.237), "o congado tem uma origem luso-afro-brasileira, uma vez que o catolicismo de Portugal forneceu os elementos europeus da devoção à Senhora do Rosário, a Igreja no Brasil reforçou a crença, enquanto os negros, de posse desses ingredientes, deram forma ao culto e à festa".

As festas ocorrem no Centro-sul do Brasil, em muitos estados do Nordeste e no Norte. Contudo, é na região sudeste que sua prática foi mais propagada, especialmente em Minas Gerais. Tem como padroeiros os Santos Católicos Nossa Senhora do Rosário, São Benedito e Santa Efigênia, que se manifestam nas festas do mês de maio, agosto ou outubro. No entanto, a crença do negro a Nossa Senhora do Rosário é precedente a vinda dos portugueses ao Brasil (SCARANO, 1976, p. 47). 
Os congadeiros, de acordo com Cascudo (2000), se trajam de branco, fitas multicoloridas, saiote e o rosário de lágrimas a tiracolo da esquerda para a direita. A dança ocorre ao ritmo das caixas e chocalhos. O cortejo é constituído pelo rei congo e/ou pela rainha que, mediante a seu embaixador, utilizando o diálogo, fazem a embaixada. Cascudo (2000, p. 50) salienta os três princípios fundamentais do congado: 1) coroação dos Reis, 2) préstitos e embaixadas e 3) reminiscência de danças guerreiras representativas de lutas.

A tradição oral destacada por Silva (2007), afirma que Galanga (Chico Rei) era um rei do Congo que foi capturado junto com sua família por portugueses e levado ao Brasil para ser vendido como escravo. No decorrer do trajeto, sua esposa, rainha Djalô e sua filha, a princesa Itulo, foram jogadas ao mar pelos marujos do navio negreiro para aplacar a ira dos deuses durante uma tempestade que quase afundou o navio negreiro. Ao chegar ao Brasil em 1740, no Rio de Janeiro, recebeu o nome de Francisco, sendo vendido junto com seu filho (Muzinga) para um major dono da mina da Encardideira, localizada em Vila Rica (atual Ouro Preto).

Com o passar dos anos, Chico teria conseguido comprar sua própria liberdade e a de seu filho e há quem diga que o escravo escondia ouro em pó nos cabelos para realizar o pagamento de sua liberdade, mas Barbosa (1965) afirma que conseguiu angariar fundos, trabalhando nos momentos de folga conseguiu angariar fundos, trabalhando nos momentos de folga dos labores servis, para alforriar seu filho, para alforriar seu filho.

Conseguindo ainda mais recursos, Chico Rei teria comprado a alforria de outros escravos e, sabendo das dívidas do seu patrão, adquiriu a mina da Encardideira que passou a se chamar mina de Francisco, "o Rei". Foi capaz de prosperar por meio do garimpo, libertando mais escravos, a maioria deles seus súditos no Congo (BARBOSA, 1965; FERREIRA, 2008).

Assim, unidos por laços de solidariedade, esses negros puderam, de certa forma, recriar sua nação. Foram instituídas as Irmandades do Rosário e de Santa Efigênia e construída sua igreja, no Alto da Cruz, onde passaram a ser realizadas as solenidades dos Reisados. Oliveira (2006), França (2011) e Monteiro (2016) afirmam que Chico Rei teria sido o primeiro rei Congo coroado em Minas Gerais em 1717 e Oliveira (2006) afirma que foi por meio das irmandades religiosas que os negros no Brasil colonial e também imperial, reconstruíram suas identidades e reinterpretaram os códigos católicos, conquistando relativa autonomia para praticarem seus cultos.

Galanga teria falecido aos 72 anos. Seu filho o sucedeu como rei do congado e Chico Rei é atualmente celebrado em festas populares por meio do canto, da dança, da procissão 
e da coroação dos reis do Congo. Geralmente as festas são realizadas em meses distintos ao longo do ano para homenagear os santos negros na data de aniversário de cada um. Como é uma figura muito importante no folclore de Ouro Preto, Chico Rei é comemorado na cidade no mês de janeiro, uma vez que organizava as solenidades no Dia de Reis.

\section{O TERRITÓRIO DAS MANIFESTAÇÕES RELIGIOSAS DA TRADIÇÃO BANTU}

O Centro Espírita São Sebastião (CESS) foi fundado na década de 1940 e está localizado no bairro Sagrada Família, bairro que carrega em seu nome forte apelo cristão. Aqui, busca-se compreender como um terreiro de umbanda, congado/reinado e candomblé de angola conseguiu permanecer em um bairro cristão e conservador por mais de 80 anos e ainda manter suas portas abertas (Figura 2).

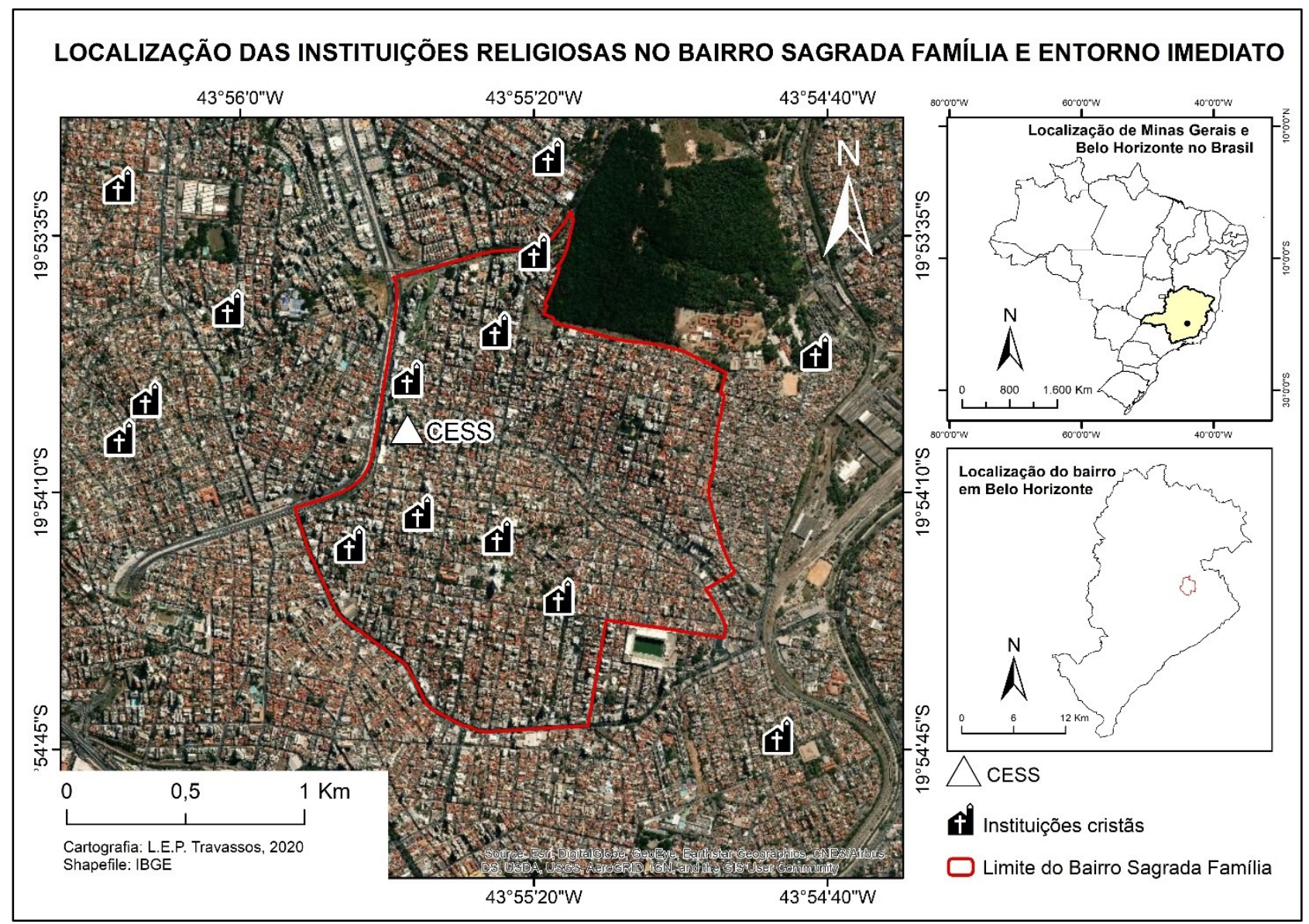

Figura 2 - Localização do CESS no Bairro Sagrada Família.

Fonte: Elaborado pelos autores

A ocupação inicial da área onde é hoje o bairro ocorreu com a criação da Colônia Agrícola Córrego da Mata, ainda durante a construção de Belo Horizonte. De acordo com Arreguy e Ribeiro (2008), tal espaço abrigavam as famílias dos operários que trabalhavam 
em algumas indústrias locais. Suas construções eram improvisadas e à medida que as famílias cresciam, os barracões ganhavam novos cômodos, agregando cada vez mais moradores. A falta de espaço fez com que a vida familiar estreitasse cada vez mais os seus laços, o que pode ter contribuído para a origem do nome do bairro: uma grande - e sagrada - família. Contudo, Arreguy e Ribeiro (2008) afirma que a origem do nome possui três versões: 1) referência ao Presépio do Pipiripau, montado no bairro; 2) sugestão do pároco da Igreja da Sagrada Família e 3) laços de amizade entre os moradores.

Já o Centro Espírita São Sebastião (CESS) foi fundado na década de 1940, pela médium D. Cecília Félix dos Santos, oriunda do distrito de Vera Cruz, em Pedro Leopoldo, Minas Gerais. Há época a fundadora sofria com a não compreensão dos fenômenos espirituais e psicofísicos que experimentava desde a adolescência e que eram considerados patologias pela sociedade.

Os fenômenos manifestavam-se com arritmias cardíacas, desmaios, fadigas, sonhos, tonturas e vozes, entre outros. Para identificar as causas de tais sintomas procurou um certo médico que a orientou a buscar um "centro espírita de mesa" (centro espírita kardecista), por acreditar que os problemas de saúde poderiam ser manifestações espirituais. A sugestão foi seguida pela D. Cecília, em Belo Horizonte, onde passou a morar e a frequentar um centro espírita desde então.

$\mathrm{Na}$ busca pela cura, passou a incorporar entidades, como exu e preto velho e, com o tempo, seguiu sua missão espiritual sincretizando aspectos religiosos kardecista e umbandista. Segundo Santos (2015, p. 39) "quando não incorporada, benzia e rezava, com diversos fins; para curar picada de animais, mau olhado, ventre virado, osso quebrado, cobreiro, e também fazia partos".

Em determinado momento, preto velho Pai Cipriano, entidade de umbanda e chefe espiritual do CESS, ordenou que a D. Cecília fundasse um terreiro e, quando criou o Centro Espírita São Sebastião, um lugar de manifestação religiosa de matriz africana de tradição Bantu, inicialmente umbandista (SANTOS, 2015, p. 40).

Em relação ao reinado, que é caracterizado pela devoção dos povos negros a Nossa Senhora do Rosário (GOMES; PEREIRA, 2000), o CESS começou nesse percurso, também, por intermédio da médium Cecília Félix dos Santos que era membro de várias irmandades. Já fraca fisicamente, iniciou a sua prática no reinado. Com o apoio de seus pares religiosos, capitães, cozinheiras, dançantes, reis, rainhas, vassalos etc., fundou a sua própria guarda nos anos 1950, porém só registrada na década de 1970 como a Guarda de Moçambique Nossa Senhora do Rosário de Pompéia. 
Nos anos 1960, acontece a inclusão do Candomblé de Angola no CESS, com a iniciação da própria D. Cecília, que passa a se chamar Mam'etu Tabaladê Ria N'Kosi (Mãe Cecília).

As territorialidades do CESS começaram a ser conhecidas e passou a abrigar os religiosos, mães e pais de santo baianos, cariocas e paulistas, que visitavam a cidade com o intuito de incorporar, impulsionar e divulgar o culto aos inquices (ancestrais). Na tradição Bantu, os inquices são cultuados e associados com os orixás de tradição lorubá, embora sejam divergentes no tocante as suas essências. Nesse sentido, os ancestrais Bantu tem relação aos familiares clânicos (clãs) e os orixás são compreendidos como fenômenos meteorológicos e que se originam de criações eventuais que representam a natureza. $\mathrm{O}$ termo orixá significa "senhor da cabeça", visto que, "ori" diz respeito à cabeça, "xá" a senhor ou rei. Logo "estes representam a energia que rege a vida dos praticantes das manifestações de matriz africana de tradição iorubá" (SANTOS, 2015, p. 41). Para Santos (2015) e Santos e Almeida (2018, p. 19) "no Candomblé verifica-se o culto aos ancestrais, os quais são seres divinos, muitas vezes ligados a forças e processos vitais (a água, os rios, montanhas, cachoeiras, o ar, a terra, a morte, a guerra, dentre outros)".

Dessa forma é possível compreender que o diálogo entre as três religiões no mesmo território demonstra a interação com o outro físico ou espiritual, uma das características essenciais Bantu, como o "cuidado ao outro que constitui um dos pilares da matriz religiosa bantu, remetendo aos laços sociais e afetivos que se promovem entre as pessoas, lideranças religiosas, os guias espirituais e os ancestrais, que compõem esse coletivo religioso (SANTOS; ALMEIDA, 2018, p. 19).

O CESS, na pessoa da D. Cecília, se destaca no cenário religioso de matriz afrincana. Como dirigente do Centro, apresentou-se como sacerdotisa nas manifestações religiosas do candomblé de angola e da umbanda, além de se tornar Rainha Perpétua na Guarda de Moçambique Nossa Senhora do Rosário de Pompéia. Participou da Associação de Umbanda e Candomblé do Estado de Minas Gerais (AUC-MG), é conselheira vitalícia na Confederação Espiritualista Umbandista de Cultos Afro-Brasileiros, do Conselho Sacerdotal de Umbanda do Estado de Minas Gerais e da Federação Espírita Umbandista do Estado de Minas Gerais (FEUEMG).

Ao longo de sua vida, a D. Cecília participou efetivamente na fundação e nas festividades públicas como a Festa de lemanjá, na Lagoa da Pampulha, e Festa dos Pretos Velhos, na Praça 13 de maio. Colaborou para a estabilização dessas manifestações de 
maneira explícita por meio de sua militância a favor dos cultos afro-brasileiros na capital e no interior de Minas Gerais.

Após o falecimento de sua dirigente em 2007, o Centro Espírita São Sebastião passou a ser gerenciado pelo filho adotivo e filho de santo da D. Cecília, o pai de santo Guaraci Maximiano dos Santos (Tatetu Yalêmi).

\subsection{A intolerância religiosa no Bairro Sagrada Família}

Desde sua fundação, devido aos sistemas de crença e valores da sociedade à época, o CESS sofreu com discriminação e perseguição. O próprio nome do território carrega a intenção de sobrevivência frente a intolerância religiosa: a expressão Centro Espírita não evidencia que o território abriga manifestações religiosas de matriz africana, pois transmite uma designação mais genérica. Já o nome de São Sebastião foi incluído por ser o santo de devoção da entidade que ordenou a construção do CESS, o preto velho Pai Cipriano, resultando em uma possível camuflagem a fim de evitar ataques e preconceitos.

Com o reconhecimento do Centro Espírita São Sebastião (CESS) em Minas Gerais e em outros estados, moradores do torno começaram a descobrir quais manifestações religiosas estavam sendo cultuadas no local. A partir de então, tiveram inicio várias ações discriminatórias que perduram até os dias de hoje. Um exemplo de uma das ações de intolerância religiosa que são sofridas pelo centro partiu de membros de uma comunidade cristã evangélica que começaram a passar "óleo ungido" no portão do CESS como forma de expulsão do "mal".

Percebe-se, assim, que a intolerância se baseia "na certeza de se possuir a verdade e no dever de impô-la a todos, pela força. Seja por determinação divina ou por vontade popular" (MEREU, 2000, p.42). Para Silva (2007, p.120), em nome da "paz eterna”, da solidariedade e da justiça, as religiões seduzem seus adeptos a atos de violência e intolerância, especialmente quando o outro se coloca como "o diferente" (SILVA, 2007, p. 120).

Em relação à intolerância religiosa, o termo violência não se refere somente a violência física, mas também, a violência simbólica. Por violência entende-se toda intervenção que limita ou proíbe a prática e execução da liberdade fundamental de um indivíduo. Assim, Oliveira afirma que, enquanto opressão social, a violência é um fenômeno estrutural que está embutido nos modelos, símbolos, hábitos, padrões e práticas inquestionáveis que compõem uma sociedade ou grupo, bem como nos pressupostos 
epistemológicos, morais e religiosos que subjazem não só a execução de papéis e tarefas sociais, culturais e religiosos prescritos, mas também às consequências individuais do seguir (ou não) códigos e normas sociais, culturais e religiosos aprovados. (OLIVEIRA, 2011).

\subsection{A Tríade Bantu no Centro Espírita São Sebastião (CESS)}

A Tríade $B_{a n t u}^{2}$ é definida como uma prática ritualística composta por três manifestações religiosas de matriz africana Bantu, ou seja, o Candomblé de Angola, o Reinado/Congado e a Umbanda, cultuadas em um mesmo território, como ocorre no Centro Espírita São Sebastião (CESS). Tal prática pode ser entendida como uma forma de garantir a sobrevivência do terreiro, oferecendo mais opções de culto e atendimento para seus frequentadores, revelando, nas palavras de Santos e Almeida (2018, p.9), habilidade das religiões afro-brasileiras em "trabalhar com o múltiplo, para fazer confluir distintas tradições culturais e religiosas, assim como distintos agentes".

Assim, as territorialidades mantidas no Centro Espírita São Sebastião manifestam uma lógica de desempenho moderada pela união dos elementos culturais africanos, ameríndios, católicos e kardecistas, na busca por validação da identidade cultural de um povo que ainda sofre com o preconceito cultural e religioso e a violência concreta e/ou simbólica, conforme destacado anteriormente.

Góis, no seu estudo sobre "O candomblé e a umbanda na cidade de Contagem, Minas Gerais - Espaço e Território", declara que o Candomblé e Umbanda são religiões de origem africana e os Reinados são expressões da religiosidade católica sob influência cultural africana. Em todo caso, compreende-se a religião como "as práticas ritualísticas que organizam a experiência de sentido ou significam a vida das pessoas que integram os grupos (...) estudados"(GÓIS, 2011, p. 70).

Fomentando a manifestação religiosa, de acordo com Guaraci Maximiano dos Santos e Arthur Henrique Nogueira Almeida,

\footnotetext{
${ }^{2}$ As religiões afro-brasileiras de matriz bantu são aquelas pertencentes à tradição étnico-linguística bantu, que, atualmente, se encontra em países como Angola, Guiné Bissau, Congo, Moçambique. Muitos representantes desse grupo etnolinguístico foram trazidos escravizados - para o Brasil e aqui protagonizaram uma reinserção criativa de suas religiões, lidando com diferentes vertentes e configurações. Entre estas, as mais conhecidas são o Candomblé de Angola, a Umbanda e o Omolocô (religião que, como a Umbanda, sincretiza elementos cristãos, espíritas e do Candomblé, com a particularidade de enfatizar o culto aos orixás). No discurso de lideranças religiosas ligadas a essas linhas, frequentemente figura o sentimento de pertencimento étnico e espiritual a uma matriz cultural e religiosa radicada em África. Desse modo, o termo bantu será utilizado neste trabalho em consonância com a sua categorização nativa, presente nos discursos e práticas dos próprios adeptos e líderes religiosos (SANTOS; ALMEIDA, 2018, p.8).
} 
no Centro Espírita São Sebastião, a multiplicidade se mostra como um elemento bastante presente nas trajetórias dos adeptos e demais seres que compõem esta comunidade afro-religiosa, bem como na história da própria fundação do terreiro, com sua matriarca Mam'etu Tabaladê Ria N'Kosi (Mãe Cecília). Ao congregar cultos da Umbanda, do Candomblé de Angola e do Reinado13, o CESS demonstra uma grande variedade de agentes, agências e rituais, os quais, no entanto, pertencem a uma mesma matriz cultural bantu. Essa matriz contribuiu para a conformação de uma grande diversidade de cultos religiosos. De maneira análoga, também o Batuque sulista estudado por Barbosa Neto (op. cit.) apresenta uma grande variedade de linhas e nações religiosas, as quais se entrecruzam a depender dos agenciamentos e da trajetória de cada terreiro específico. A este respeito, o autor chega a afirmar que "cada casa é um caso" (BARBOSA NETO, op. cit., p.1), ou seja, cada terreiro possui seu próprio modo de fazer religião afro-brasileira, sua própria malha de agentes (adeptos, orixás, espíritos antepassados, etc.) construída ao longo do tempo e das relações entre esses (SANTOS; ALMEIDA, 2018, p. 17-18).

\subsubsection{A Umbanda no Centro Espírita São Sebastião (CESS)}

No rito umbandista do Centro Espírita São Sebastião (CESS) é possível observar a hierarquia dentro do terreiro, os pontos cantados e riscados, o toque dos atabaques e a chegada das entidades.

A hierarquia na umbanda "(...) depende da capacidade de liderança religiosa dos médiuns e de seus guias espirituais" (MORAIS, 2010, p.101), e que os pressupostos religiosos estão bem conectados à fala da entidade de quem comanda o território.

Há, também, o assentamento da esquerda ${ }^{3}$, os banhos de descarrego para os médiuns precedente aos rituais, as guias no pescoço e as defumações. Nota-se a utilização de velas, a abstinência alcoólica, sexual e alimentar um dia antes da sessão. Valem-se de rezas católicas, como a Ave-Maria, o Credo, o Pai-Nosso, a Salve Rainha, como também as kardecistas, a prece de Cáritas e a de Ismael.

As marcas do sincretismo religioso umbandista são evidenciadas no congá ${ }^{4}$ com a existência de elementos ameríndios, arcos, estátuas de índios e caboclos, flechas, imagens católicas e representações africanas (imagens de entidades como os pretos velhos). Observa-se, também, elementos que remetem ao candomblé de Angola e a tradição do Reinado.

Infere-se que o congá, no CESS, é um espaço de convergência simbólica em que a religiosidade gera sentido por meio da competência de articulação do ser humano perante as tradições ameríndias, católicas, candomblecista, do reinado e umbandista (Figura 3).

\footnotetext{
${ }^{3}$ Casa de Exus / Pombogiras como guardiões do lado externo do terreiro.

${ }^{4}$ Nome dado aos altares.
} 


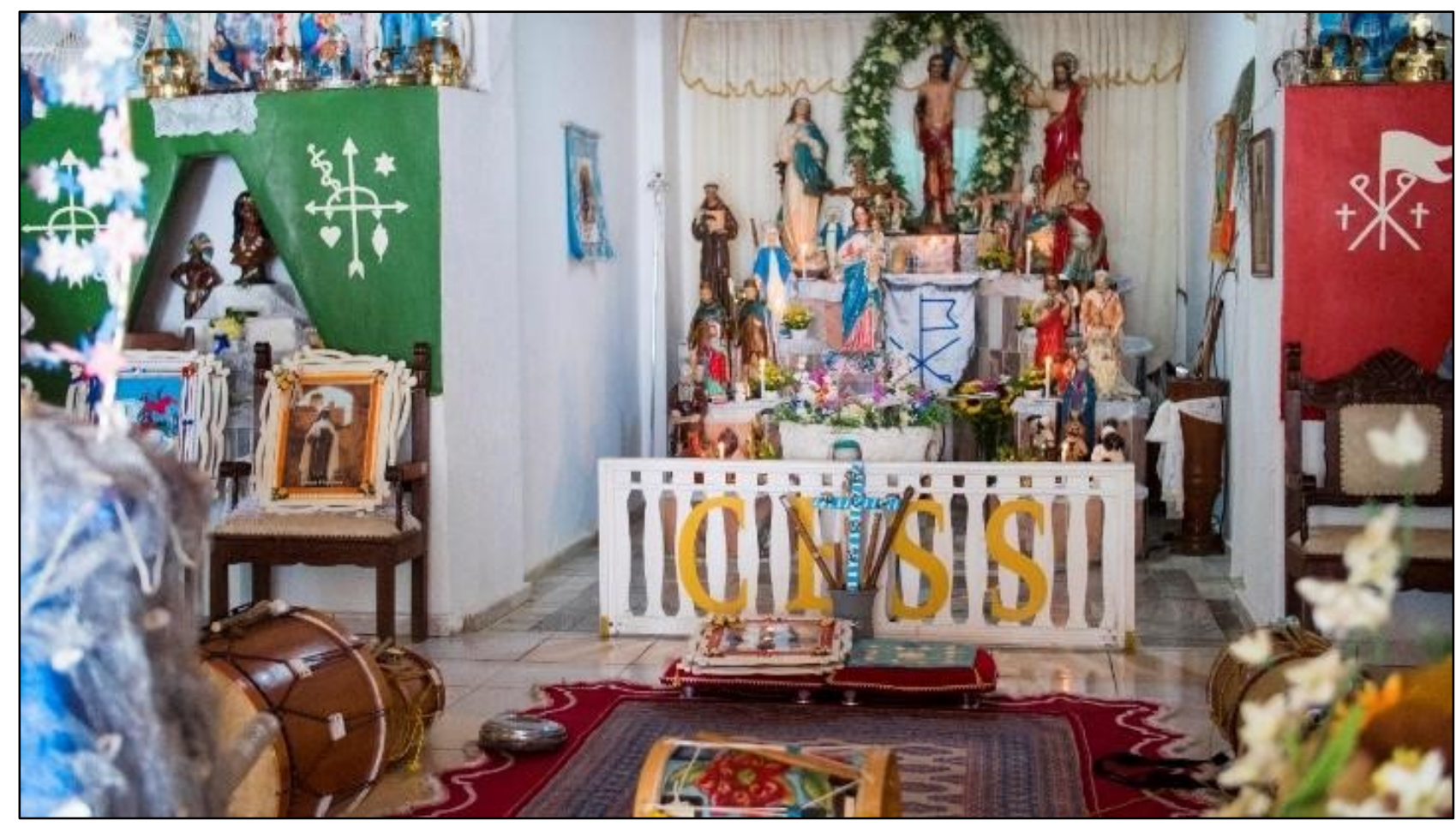

Figura 3 - Altares do CESS em dia de Congado.

Fonte: Foto de Leonardo Catapreta

Na Umbanda, os médiuns devem dedicar parte de seu tempo a várias tarefas, pois são responsáveis pela limpeza, manutenção e sustentação financeira da casa. De acordo com Bosi (1992), ocorre uma ressignificação por meio da arte e da introdução de preceitos africanos que são entendidos e reelaborados no congá perante os pilares do espiritualismo e organizados em nome da religião, da filosofia e da ciência. Dessa forma, percebe-se a Umbanda como uma manifestação heterogênea de religiosidade popular brasileira norteada pela ancestralidade cultural afrodescendente, "que mantêm fortes vínculos de identidade, referência e transmigração de costumes originados na matriz africana Bantu" (SANTOS, 2015, p.49).

\subsubsection{O Reinado no Centro Espírita São Sebastião (CESS)}

Existem dois momentos principais de louvação na prática do reinado no CESS. O primeiro é atribuído a Nossa Senhora do Rosário de Pompéia e a outros sete santos (Senhora Aparecida, Santa Efigênia, Santa Luzia, Santo Antônio, São Benedito, São Jorge e São Sebastião) que tem suas bandeiras hasteadas no segundo final de semana de outubro (Figura 4). Já o segundo momento ocorre no último final de semana de novembro, na celebração à Senhora das Graças. São louvados outros santos, como Senhora do 
Carmo, Senhora da Guia, Senhora do Perpétuo Socorro, São Bento, Santo Expedito e São Pedro.

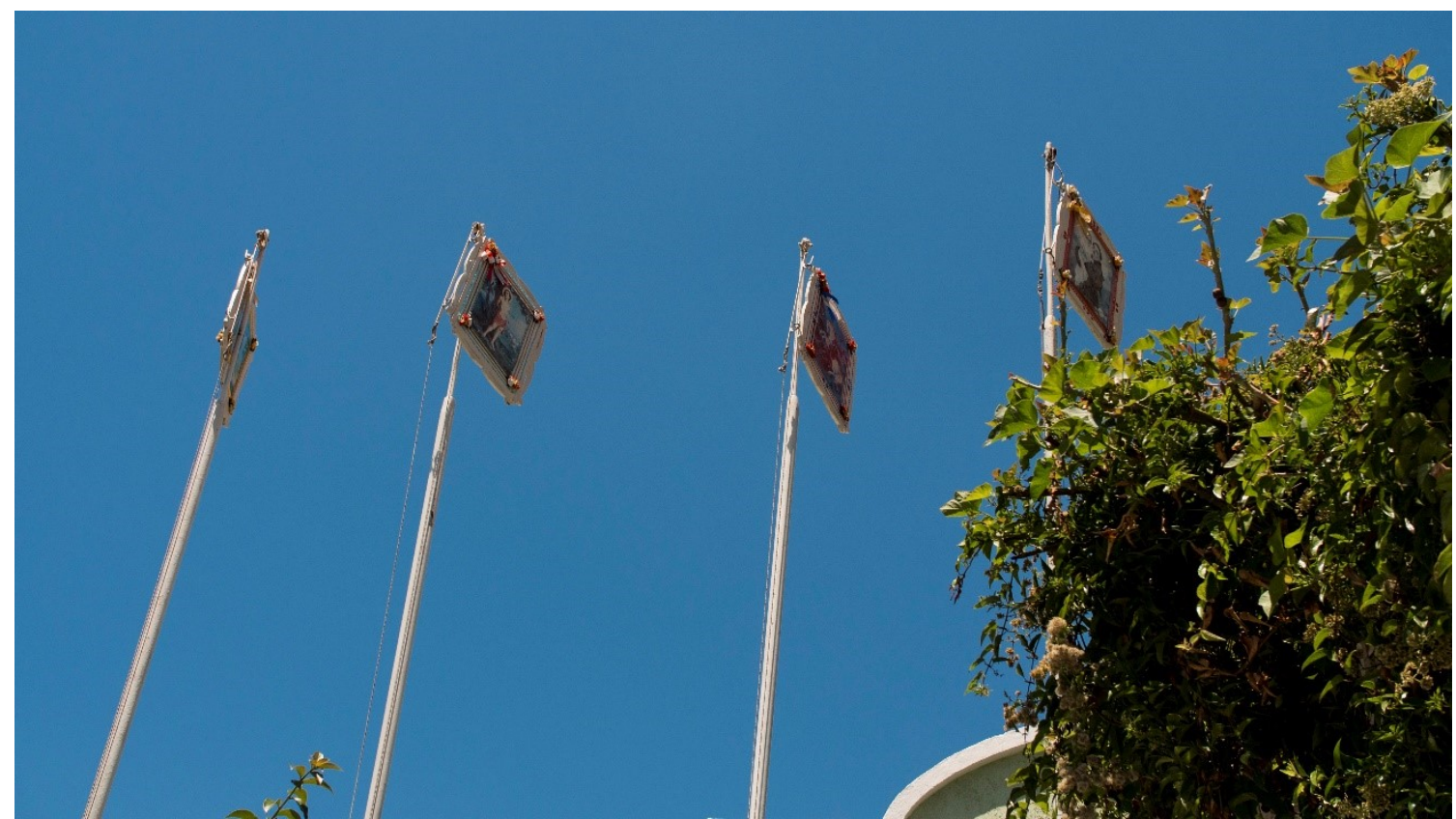

Figura 4 - Bandeiras dos santos hasteadas em frente ao CESS.

Fonte: Foto de Leonardo Catapreta.

No decorrer da pesquisa, notou-se que os rituais das festas do Rosário tem início quinze dias antes da data, com as novenas abertas ao público e que são realizadas pelas rainhas, reis e membros da guarda. Há o hasteamento da bandeira de aviso estampada com a imagem da santa celebrada.

Em certos momentos, entoam-se cantigas. As orações são entoadas pelos capitães e são respondidas pelos membros da guarda, acompanhados por instrumentos musicais, como gungas ${ }^{5}$, patangômes ${ }^{6}$ e tambores, tocados pelos caixeiros e dançantes.

Os cânticos são formas de oração em busca da comunhão com o divino, ou seja, um caminho de convívio e clamor religioso dos devotos. "Todo o processo é simbólico e religioso, sacralizado a partir de sua dinâmica das rezas e das bênçãos" (SANTOS, 2015, p. 51) que são praticadas ao longo de todo o ritual do festejo.

O ritual prossegue com um cortejo que obedece a hierarquia do reino. À frente temse a bandeireira, que traz a bandeira da Senhora do Rosário de Pompéia. A bandeireira é amparada pelos caixeiros e capitães, aqueles que cantam e conduzem todo o percurso da guarda, do barracão (CESS) ao mastro.

\footnotetext{
${ }^{5}$ Latinhas fechadas com sementes (principalmente caetés) dentro, presas a uma correia de couro e amarradas aos tornozelos. Conjugam a fusão do som e da dança dos movimentos dos dançantes.

${ }^{6}$ Instrumentos de percussão feitos com latas grandes, folhas de latão ou com calotas de automóveis, cheias com chumbinho ou sementes, usadas durante as louvações de reinado.
} 
A cerimônia do hasteamento das bandeiras é conduzida de modo contínuo, segundo a tradição determinada ao longo dos anos. O rito é finalizado em um momento de convivência quando é servido um café, abençoado por São Benedito, com quitandas caseiras significando a fartura e o provento.

No decorrer da festa ocorre a chegada de guardas de outros reinos e visitantes da comunidade. Há, entre as guardas, cumprimentos e saudações com cânticos de respeito.

Após o almoço acontece a procissão pelos arredores do CESS. A procissão deslocase pelas ruas adjacentes (Itajubá, Godofredo de Araújo e São Lázaro), conforme Figura 5. Ela é saudada por fogos de artifício e pela participação do corpo social, quando são guiados os andores da Senhora do Rosário e de São Benedito.

Ao final da procissão ocorre uma missa conga, diferente do ritual católico, respeitando um modelo oferecido pela tradição afrodescendente, o Reinado. A guarda da Senhora do Rosário de Pompéia orienta-se para a missa segundo uma programação própria que inclui pontos como o ofertório da água, do fogo, da terra e do ar. Os cânticos, em sintonia de agradecimento, tanto na entrada quanto na saída do lugar sagrado, são acompanhados por instrumentos de percussão. Atualmente, no CESS, a missa tradicional da Festa do Rosário é realizada no seu interior.

Logo após a missa, os guardas visitantes, as do CESS e outros membros da comunidade retornam à mesa para o jantar. Os cânticos de gratidão e bênçãos são novamente entoados acompanhados pelos instrumentos de percussão. Após o jantar, retorna-se ao barracão (CESS) para a "descoroação" (entrega das coroas). No decorrer da pesquisa foi evidente a existência de forte carga emocional.

Para Martins (2002, p. 23), o reinado se define pelo

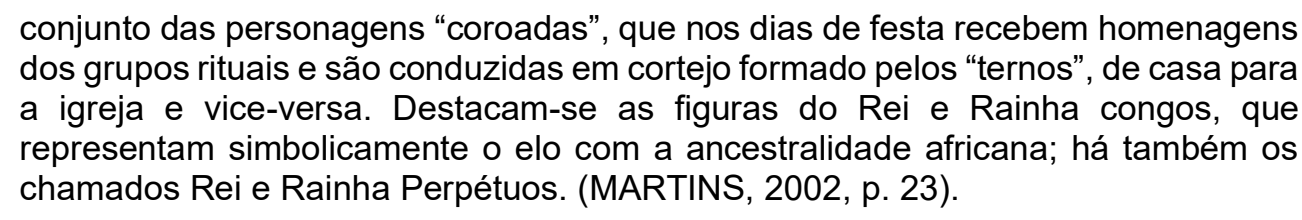

Os festejos só terminam com o "descimento" das bandeiras, uma semana após o início da festa. Ao final, toda organização (e.g.: altares, andores, mesas etc.) é desfeita. Os bastões, as coroas e as espadas retornam aos seus lugares no altar do CESS e as bandeiras regressam para a parte superior do pejís ${ }^{7}$ menores, onde ficam até os próximos festejos (Figura 6).

\footnotetext{
${ }^{7}$ Altares.
} 


\section{TRAJETO DA PROCISSÃO DO REINADO NO DIA DA PADROEIRA}

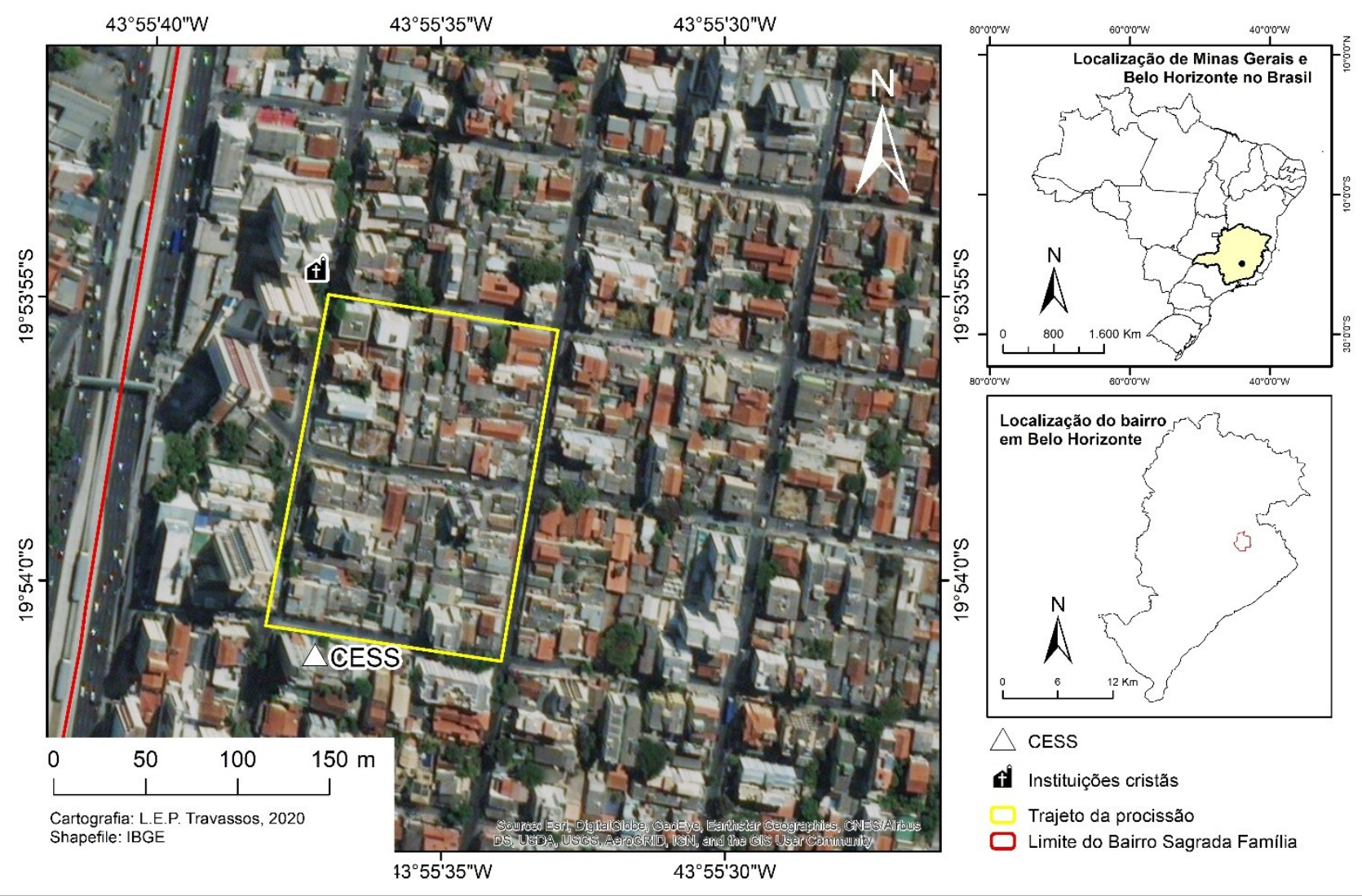

Figura 5 - Trajeto da procissão do Reinado realizada pelo CESS.

Fonte: Elaborado pelos autores

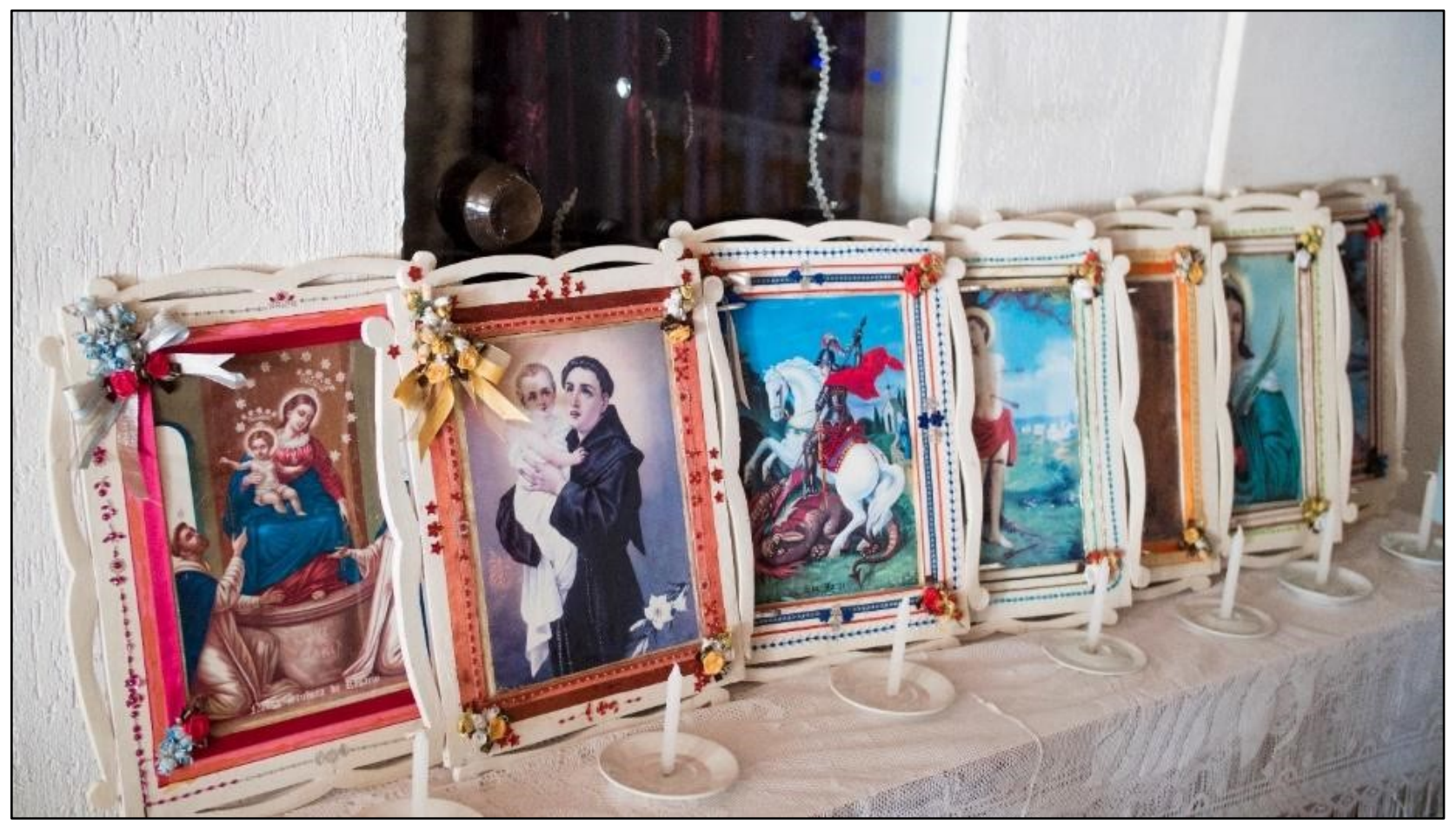

Figura 6 - As bandeiras dos santos preparadas para a próxima festividade.

Fonte: Foto de Leonardo Catapreta 


\subsubsection{O Candomblé no Centro Espírita São Sebastião (CESS)}

A iniciação dos filhos-de-santo é uma forma de ingresso à religião e tem seu clímax na sacralização, isto é, na oferenda de animais aos inquices ${ }^{8}$ que é seguida de outros rituais, como banhos e beberagens. A respeito do processo de iniciação nas manifestações religiosas de matriz africana, Silva destaca que:

(...) a importância de pertencer a uma linhagem advém, portanto, do reconhecimento público da legitimidade da iniciação e do sacerdócio. E mais ainda, no candomblé acredita-se que só possui e pode passar "axé" (força vital) aqueles que o receberam, isto é, que foram iniciados por pessoas também iniciadas. $O$ conhecimento da genealogia mítica de cada membro ou grupo atestaria a ininterrupção da transmissão do axé através das gerações. Pertencer a uma linhagem de um terreiro renomado e antigo é sinal de prestígio pela "qualidade" do axé que se recebe e se transmite. (SILVA, 1995, p. 114).

Nota-se que o Candomblé de Angola no CESS é marcado pela iniciação, que acontece a partir do "bolar no santo" (entrar em transe) em um certo ritual anterior à iniciação. O adepto é conduzido para a camarinha ${ }^{9}$, momento em que é acertado e comunicado a vontade de seu inquice sobre a necessidade de sua iniciação. Dependendo das condições financeiras e sociais que podem impedir a pessoa "de fazer o santo", o terreiro realiza um bori, ou seja, um dos primeiros rituais de iniciação. A partir de então, a mãe e/ou pai-de-santo consulta os búzios com a intenção de prever prováveis obstáculos e quais ebós ${ }^{10}$ são fundamentais antes do recolhimento da pessoa na casa para o processo de iniciação.

Contribuem nos processos do Candomblé de Angola e nos rituais as Macotas, Cotas e Tatas Kambondos que, mesmo não entrando em transe, passam da mesma forma pelo "toque de bolar" (ritual ritmado pelos sons dos atabaques), com a intenção de louvar o inquice e favorecer o transe. O não entrar em transe por parte de alguns adeptos, estabelece que estes estarão capacitados ao processo de iniciação nos cargos acima.

Já o adepto que entrar em transe cuidará do seu enxoval do santo e a manutenção das pessoas que o auxiliarão na camarinha. O seu recolhimento começará, no terreiro, ao som dos atabaques quando o médium dançará para seu inquice e, por ele, será tomado, excorporado, identificando este iniciado como um rodante, aquele que vira no santo. Tal processo permite ao adepto conhecer as práticas e os rituais, confinado na camarinha, retirando-se do local exclusivamente para as cerimônias essenciais. Durante o período de

\footnotetext{
${ }^{8}$ Ancestrais.

9 Quarto de descanso.

${ }^{10}$ Oferendas, sacrifícios e/ou sacralizações aos ancestrais
} 
purificação de vinte e um dias, tem início a cerimônia de assentamento do inquice, no qual a cabeça do adepto e o ibá ${ }^{11}$ recebem menga ${ }^{12}$ da sacralização dos animais, como os aberês $^{13}$, que, segundo Silva:

(...) são feitos na cabeça, na região da moleira, por onde se acredita entrar o espírito do orixá e onde será posicionado o "oxu" (espécie de amálgama feito com elementos vegetais e sangue, em forma de cone). Também na língua, (aqui simbolicamente ou não), braços, costas, peito e sola dos pés são feitas essas marcas. Tradicionalmente devem ser feitas com uma navalha sacralizada que o pai-de-santo recebeu por ocasião de seu "deca". (SILVA, 1995, p. 133).

Percebe-se que os aberês retratam o fechamento do corpo, pois depois de realizados, nada de mal pode entrar no adepto. O cumprimento de sete anos de iniciação presenteia ao adepto o direito de possuir seu próprio terreiro e conceber sua própria família espiritual. Ou seja, a obrigação ritualística conhecida como Decá ${ }^{4}$, permite ao adepto receber o título de sacerdotisa ou sacerdote no Candomblé de Angola.

A cerimônia caracteriza o adepto como Mametu (mãe) ou Tatetu (pai), ainda que o graduado ainda precise ser acompanhado por um mais velho que, no começo, ajudará este novo sacerdote.

Entre os compromissos que se deve ter quando recebido o Decá, destaca-se o da restrição alimentar que deve ser considerado na vida espiritual. O iniciado não deve se alimentar das vísceras dos animais, pois elas retratam a ampliação do $n g u z 0^{15}$ do animal sacralizado. D o animal ofertado ao inquice participante de alguma obrigação ${ }^{16}$, o muzenza ${ }^{17}$, bem como o Mametu (mãe) ou Tatetu (pai) não se pode comer nada. Os outros integrantes da cerimônia interna ou externa têm de se alimentar da carne, visto que a carne é compreendida como a extensão da força vital de todo o ritual.

Da mesma forma existem preceitos comportamentais e sexuais. A abstenção simboliza a preservação da pureza e sintonia para com o inquice, representando a sacralização do corpo, além de buscar a interdição do incesto dentro da família de santo. Quando não obedecidos os preceitos, ocorrem quizilas ${ }^{18}$ e proibições em sua ação religiosa (SILVA, 1995).

Destaca-se que durante a pesquisa foram observadas algumas mudanças nos rituais do CESS. O principal foi a atenuação do tempo de iniciação que vêm sendo propostas por

\footnotetext{
${ }^{11}$ Recipiente composto por objetos sagrados sacralizados nos rituais de iniciação.

12 Sangue.

13 Incisões, cortes feitos com navalha.

14 Obrigação de sete anos.

${ }^{15}$ Força vital / axé.

${ }^{16}$ Ritual.

17 Iniciado na tradição.

${ }^{18}$ Reações de adversidade a algo.
} 
mães e pais-de-santo a fim de acolher as necessidades atuais de culto em cidades muito urbanizadas. Além disso, identificou-se a alternância dos horários das cerimônias públicas para que seja possível conservar o bom convívio social, o bem-estar e a segurança dos adeptos e frequentadores.

Recentemente, diante da gravidade da pandemia da COVID-19 e em conformidade com as determinações das autoridades, o CEES suspendeu temporariamente todas as atividades e festividades públicas do terreiro.

A pesquisa observou que o sagrado do Candomblé de Angola no CESS é bem delineado e reconhecido ao recorrer a determinados preceitos, proibições e sincretismos que são os mediadores das condutas de seus fiéis (Figura 7).

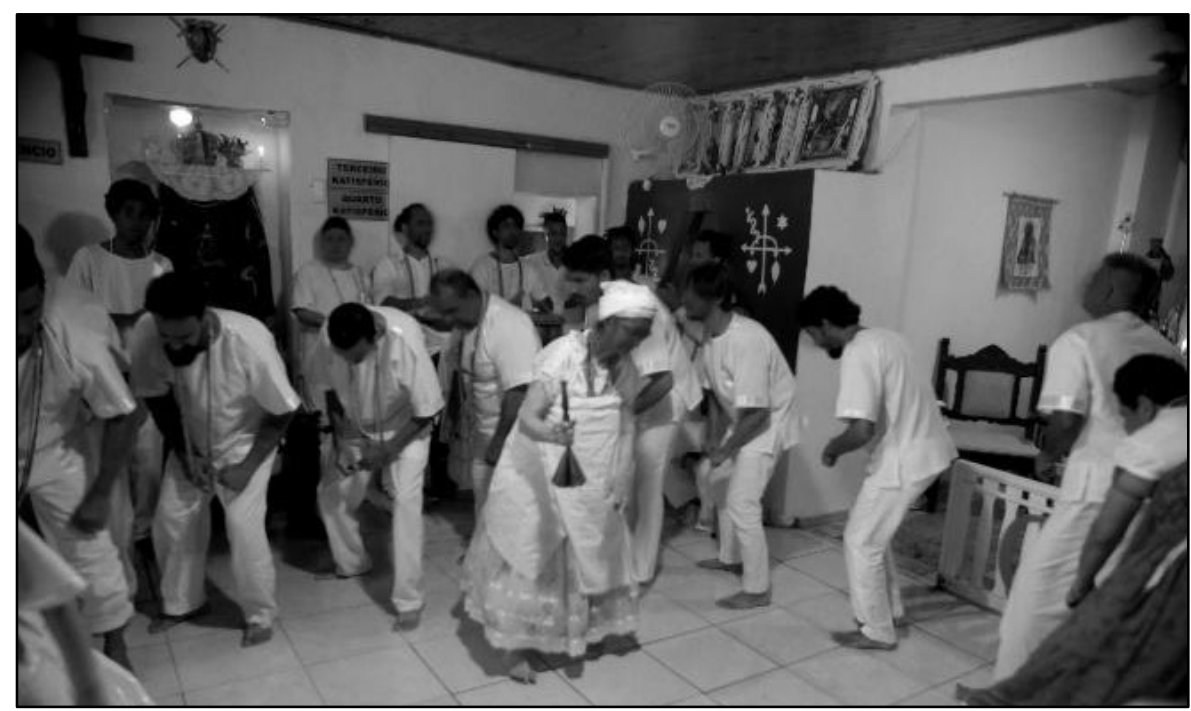

Figura 7 - Roda de Candomblé no CEES.

Fonte: Foto de Leonardo Catapreta

\section{CONCLUSÕES}

As territorialidades presentes no CESS são definidas pela tríade Bantu, composta por três religiões de matriz africana, a Umbanda, o Reinado/Congado e o Candomblé de Angola. Observa-se que a coexistência das três religiões em um mesmo espaço é uma forma de sobrevivência que também possibilita a ampliação do público.

Durante a realização da pesquisa, observaram-se as particularidades de cada uma das religiões. Na Umbanda, nota-se o sincretismo com as rezas e os santos católicos junto às representações africanas e ameríndias. No Reinado/Congado, as expressões contemplativas reportam-se a uma edificação mais direta em relação à referência aos antepassados e ao espaço sagrado com os traços das práticas cristãs. Já no Candomblé de Angola, percebe-se que é a mais africana das religiões do CESS. A subordinação na 
entrega do médium aos inquices é a forma de reconhecimento dele com o outro; seja o indivíduo, seja o espírito.

No CESS, as religiões da tradição Bantu vivem em harmonia, principalmente por apresentarem um eixo comum em direção à ancestralidade do terreiro. As manifestações são bem consolidadas e se traduzem em rituais bem distintos que as diferenciam entre si. Os ritos são desenvolvidos em momentos específicos a fim de buscarem, cada um, a sua harmonia e a sua energia.

Foi possível perceber que a convivência das práticas religiosas no mesmo território estabelece um arranjo específico das manifestações de matriz africana Bantu tanto quanto às crenças, quanto aos ritos. No CESS, ao se conservar as características das religiões observa-se que as três se complementam, se mesclam e se relacionam. Dessa forma, o CESS representa um espaço sagrado desenvolvido em prol da continuidade das religiões Bantu.

\section{REFERÊNCIAS}

ALTUNA, R. R. de A. Cultura tradicional Banto. Luanda: Secretariado arquidiocesano de Pastoral, 1985.

ARREGUY, C. A. C.; RIBEIRO, R. R. Histórias de bairros de Belo Horizonte: Regional Leste. Belo Horizonte: APCBH, 2008. Disponível em: http://www.pbh.gov.br/historia bairros/ LesteCompleto.pdf. Acesso em 24 jun. 2020.

ASSOCIAÇÃO de moradores e empresários do bairro Sagrada Família (Belo Horizonte).História do bairro Sagrada Família. Belo Horizonte, 2014. Disponível em: http://amesagradafamilia.org.br/plus/modulos/conteudo/?tac=do-bairro Acesso em: 19 ago. 2019.

BARBOSA JR., A. Novo dicionário de Umbanda. São Paulo: Universo dos Livros Editora, 2014.

BARBOSA JR., A. O livro essencial de umbanda. São Paulo: Universo dos livros, 2014.

BARBOSA, W. de A. O Congado no Oeste mineiro. Revista brasileira do folclore, Rio de Janeiro, v. 5, n. 11, p. 5-22, jan./abr, 1965.

BASTIDE, R. As religiões africanas no Brasil. São Paulo: Pioneira, 1971.

BASTIDE, R. O sagrado selvagem e outros ensaios. São Paulo: Companhia das Letras, 2006. 
BASTIDE, R. As religiões africanas no Brasil. São Paulo: Pioneira, 1971.

BOSI, A. A dialética da colonização. São Paulo: Companhia das Letras, 1992.

CARNEIRO, E. Religiões negras e negros bantos. 3.ed. Rio de Janeiro: Civilização Brasileira, 1991.

CARNEIRO, E.; RAMOS, A. (coord.). Religiões negras. Rio de Janeiro: Civilização Brasileira S/A, 1936.

CASCUDO, L. da C. Dicionário do folclore brasileiro. 9.ed. Rio de Janeiro: Ed. Global, 2000.

CESS - CENTRO ESPÍRITA SÃO SEBASTIÃO. Página Oficial. Disponível em: $\underline{\text { http://cess- }}$ blog.blogspot.com/search/label/CURSOS. Acesso em: 15 Fev. 2020.

COSTA, J. R. da. Candomblé de Angola: Nação Kassanje. História, etnia, inkises, dialeto litúrgico dos Kassanjes. 3.ed. Rio de Janeiro: Pallas, 1996.

FAUSTO, B. História do Brasil. São Paulo: Fundação do Desenvolvimento da Educação, 1995.

FERREIRA, R. de S. Origens da congada: controvérsias e convergências. Unimontes Científica, v. 7, n. 2, p. 101-112, 2008.

FRANÇA, C. C.; POPOFF, Y. Festa mestiça: o congado na sala de aula. Belo Horizonte: Universidade Federal de Minas Gerais, 2011.

GÓIS, A.J. O candomblé e a umbanda na cidade de Contagem, Minas Gerais: espaço e território. 2011. Tese (Doutorado em Geografia) - Pontifícia Universidade Católica de Minas Gerais, 2011.

GÓIS, A.J. O espaço e o território sagrados do candomblé e da umbanda em Contagem, Minas Gerais. Revista Ciências da Religião, v. 11, n. 1, p. 14-38, 2013.

GOMES, N. P. de M.; PEREIRA, E. de A. Negras raízes mineiras: os Arturos. Belo Horizonte: Mazza, 2000.

KARDEC, A. O Livro dos Médiuns. Rio de janeiro: Federação Espírita Brasileira, 2003.

KILEUY, O.; OXAGUIÃ, V.; BARROS, M. (org.). O candomblé bem explicado: Nações bantu, iorubá e fon. Rio de Janeiro: Pallas, 2016.

KOZEL, S. As representações no geográfico. In: MENDONÇA, F.; KOZEL, S. (Org.) Elementos de Epistemologia da Geografia Contemporânea. Curitiba: E. UFPR, 2002, p.215-232. 
MONTEIRO, L. N. A origem mítica das festas de Congada e as memórias da escravidão no tempo presente em Minas Gerais. Revista OQ, v.3, n.3, 2016.

MARTINS, L. M. Performances do tempo espiralar. In: RAVETTI, G.; ARBAX, M. (Org.). Performance, exílio, fronteiras: errâncias territoriais e textuais. Belo Horizonte: FALE/UFMG, 2002. p.69-91.

MEREU, I. A intolerância institucional; origem e instauração de um sistema sempre dissimulado. In: BARRET-DUCROCQ, F. A intolerância. Rio de Janeiro: Bertrand Brasil, 2000. p.42-45.

MORAIS, M. R. Nas teias do sagrado: registro da religiosidade afro-brasileira em Belo Horizonte. Belo Horizonte: Ampliar, 2010.

NERY, C. Um Olhar sobre o Congado das Minas Gerais. Belo Horizonte: Cristiane Gusmão Nery, 2012.

OLIVEIRA, A.J.M. de. Devoção e identidades: significados do culto de Santo Elesbão e Santa Efigênia no Rio de Janeiro e nas Minas Gerais no Setecentos. Topoi, v.7, n.12, p. 60115, 2006.

OLIVEIRA, I.D de. Religiões afro-brasileiras e violência. Revista Ciberteologia: Revista de Teologia e Cultura, v.7, n.35, 2011.

OLIVEIRA, I. D. de; JORGE, E. F. C. Espiritualidade umbandista: recriando espaços de inclusão. Revista Horizonte, Belo Horizonte, v. 11, n. 29, p. 29-52, jan./mar. 2013. Disponível em: http://periodicos.pucminas.br/index.php/horizonte/article/view/P.21755 841.2013v11n29p29/5085 Acesso em: 04 jan. 2020.

OLIVEIRA, J. H. M. de. Uma discussão teórica sobre as interpretações do mito fundador da Umbanda, RJHR, v.6, n.11, 2013.

PEREIRA, C. J. Geografia da religião: um olhar panorâmico. RAEGA: O espaço geográfico em análise, Curitiba, v. 27, p. 10-37, 2013. Disponível em: https://revistas.ufpr.br/raega/ article/view/30414/19689. Acesso em: 1 out. 2019.

RAMOS, A. O negro brasileiro. 5. ed. Rio de Janeiro: Graphia, 2001.

ROSENDAHL, Z. Espaço e Religião: uma abordagem geográfica. Rio de Janeiro: UERJ, 1996.

ROSENDAHL, Z. O Espaço, o Sagrado e o Profano. In: ROSENDAHL, Z.; CORREA, R.L.(Org.) Manifestações da Cultura no Espaço. Rio de Janeiro: UERJ, 1999.

ROSENDAHL, Z. Espaço e Religião: Uma Abordagem Geográfica. Rio de Janeiro: UERJ, 2002. 
ROSENDAHL, Z. Espaço, Cultura e Religião: dimensões de análise. In: CORRÊA, R.L.; ROSENDAHL, Z. (Orgs.). Introdução à geografia cultural. Rio de Janeiro: Betrand Brasil, 2003. p.187-224.

ROSENDAHL, Z. Representações do Sagrado: ratificando o domínio da emoção e do sentimento do ser-no-mundo. In: COLÓQUIO NACIONAL DO NÚCLEO DE ESTUDOS EM ESPAÇO E REPRESENTAÇÕES, 1, 2007. Anais... São Paulo: USP, 2007. 1CD-ROOM.

SAHR, W.D. Signos e Espaço Mundos - A semiótica da espacialização na geografia cultural. In: KOZEL, S.; SILVA, J. da C.; GIL FILHO, S.F. (Orgs.) Da Percepção e Cognição à Representação: reconstruções teóricas da geografia cultural e humanista. São Paulo: Terceira Margem: Curitiba: NEER, 2007.

SAHR, W.D. Religion and Scientificism in Brazil, towards a Regional Geography of Knowledge: a Geographical Essay. Revista de História Regional, v.6, n.2, p.43-74, 2001.

SANTOS, C.R.M. dos. Congada e Reinado: história religiosa da irmandade negra em Jequitibá-MG. HORIZONTE: Revista de Estudos de Teologia e Ciências da Religião, v.10, n. 26, 2012.

SANTOS, G.M. dos. Umbanda, Reinado e Candomblé de Angola: uma tríade Bantu na promoção da vida responsável. HORIZONTE-Revista de Estudos de Teologia e Ciências da Religião, v. 13, n. 39, p. 1698-1700, 1 out. 2015.

SANTOS, G.M.dos; ALMEIDA, A.H.N. Confluências Bantu: multiplicidade, resistência e cura. Revista Calundu, v.2, n.2, 2018.

SCARANO, J. Devoção e escravidão: a Irmandade de N. Sra. do Rosário dos Pretos do distrito Diamantino no séc. XVIII. São Paulo: Cia. Nacional, 1976.

SILVA, R.A.da. Chico Rei Congo do Brasil. Memória Afro-Brasileira: Imaginário, cotidiano e Poder. São Paulo: Selo Negro, 2007.

SILVA, V. G da. Intolerância religiosa: impactos do neopentecostalismo no campo religioso afro-brasileiro. São Paulo: Edusp, 2007.

SILVA, V. G. Orixás da metrópole. Petrópolis: Vozes, 1995.

SILVA, V. G. Candomblé e umbanda: caminhos da devoção brasileira. 2. ed. São Paulo: Selo Negro, 2005.

SOUZA, M. de M. Reis negros no Brasil escravista: história da festa de coroação de rei congo. Belo Horizonte: Ed. UFMG, 2001.

TUAN, Yi-Fu. Espaço e Lugar: A Perspectiva da Experiência (1977). São Paulo: Difel/Difusão Editorial, 1983. Tradução Lívia de Oliveira. 
TUAN, Yi-Fu. Paisagens do medo (1979). São Paulo: Ed.Unesp, 2006. Tradução de Livia de Oliveira.

TUAN, Yi-Fu. Topofilia: Um Estudo da Percepção, Atitudes e Valores de Meio Ambiente (1974). São Paulo: Difel/Difusão Editorial, 1980. Tradução Lívia de Oliveira.

VARGAS, I. A. de. Paisagem, Território e Identidade: uma abordagem da geografia cultural para o pantanal Mato-Grossense. In: KOZEL, S.; SILVA, J. da C.; GIL FILHO, S.F. (Orgs.). Da Percepção e Cognição à Representação: reconstruções teóricas da geografia cultural e humanista. São Paulo: Terceira Margem; Curitiba: NEER, 2007.

VICENTE, J.A. A experiência salvífica na religião tradicional dos povos banto e a teologia do concílio vaticano II: Pistas para o diálogo inter-religioso a partir do paradigma missão evangelizadora da igreja. 2012. 137f. Dissertação (Mestrado/Teologia) - Faculdade Jesuíta de Filosofia e Teologia, Belo Horizonte, 2012. Disponível em: https://www.faculdadejesuita. edu.br/documentos/280612-QV8iY3qGwNDXJ.pdf. Acesso em: 14 ago. 2019. 